\title{
The prevalence of osteopenia and osteoporosis in patients with chronic obstructive pulmonary disease and their relation with disease severity
}

Kronik obstrüktif akciğer hastalığ॥ olan hastalarda osteopeni ve osteoporoz sıklığı ve hastalık şiddeti ile ilişkisi

\section{Fatma Yıldırım ${ }^{1}$, Esra Meltem Koç ${ }^{2}$, Tugba Körlï Akkale ${ }^{3}$, Sakine Nazik Bahçecioğlu ${ }^{4}$, Nurdan Köktiürk ${ }^{5}$}

${ }^{1}$ Department of Pulmonary \&Critical Care Medicine, University of Health Sciences, Dışkapı Yıldııım Beyazıt Research and Education Hospital

Ankara, Turkey

${ }^{2}$ Department of Family Medicine, İzmir Katip Çelebi University, Faculty of Medicine, İzmir, Turkey

${ }^{3}$ Clinic of Pulmonary Medicine, Ministry of Health, Urla State Hospital, İzmir, Turkey

${ }^{4}$ Department of Pulmonary Medicine, Subdivision of Allergy and Immunology, Erciyes University, Faculty of Medicine, Kayseri, Turkey

${ }^{5}$ Department of Pulmonary Medicine, Gazi University, Faculty of Medicine, Ankara, Turkey

Corresponding author: Fatma Yıldırım, MD., Department of Pulmonary \&Critical Care Medicine, University of Health Sciences, Dışkapı Yıldırım

Beyazıt Research and Education Hospital, Ankara, Turkey

E-mail: ftagassi@hotmail.com

Received/Accepted: March 06, 2019 / March 12, 2019

Conflict of interest: There is not a conflict of interest.

\section{SUMMARY}

Objective: Osteopenia and osteoporosis are within the systemic features of chronic obstructive pulmonary disease (COPD). The present study aimed to investigate the frequency of osteopenia and osteoporosis in COPD patients and to determine the correlation between bone mineral dansity (BMD) and the clinical characteristics of COPD patients.

Method: This retrospective study was conducted in the department of Pulmonary Medicine, at a university hospital in Turkey between January 2014 to August 2016. Data of 92 patients with COPD who underwent dual energy X-ray absorptiometry to evaluate BMD were extracted from the medical records. Osteopenia/osteoporosis was assessed with the $\mathrm{T}$ and $\mathrm{Z}$ scores.

Results: Mean age of the patients was $66.2 \pm 9.2$ years and males comprised $89.1 \%$ of the study group. The frequency of osteopenia/osteoporosis in the COPD patients was 63.0\%. Osteopenia/osteoporosis frequency was same in GOLD C/D and GOLD A/B patients [12/19 (\%63.1) and 46/73 (\%63.1)]. Exacerbation number in the previous year and the readmission rates were higher and the duration of hospital stay of the patients with osteoporosis was longer $(\mathrm{p}<0.05)$. A significant positive correlation was noted between body mass index and BMD ( $r=0.489, p<0.001)$, BMD and FEV1/FVC $(r=0.226, p=0.040)$, exacerbation number in the previous year $(r=-0.429, p=0.001)$ and the duration of hospital stay in admission $(\mathrm{r}=-0.228, \mathrm{p}=0.034)$. As the severity of GOLD stage increased, the prevalence of osteopenia was also increased $\left(\mathrm{p}_{\text {trend }}<0.001\right)$.

Conclusions: Our data suggest that the prevalence of osteopenia and osteoporosis in COPD patients is high independent of disease stage. Abnormal BMD results are associated with frequent exacerbation, prolongation of hospital stay, and poor course of the disease.

Key words: Chronic obstructive pulmonary disease, osteopenia, bone mineral density, osteoporosis, forced expiratory volume in 1 second (FEV1)/ forced vital capacity (FVC)

\section{ÖZET}


Yöntem: Bu retrospektif çalışma Türkiye'deki bir üniversite hastanesinde Göğüs Hastalıkları bölümünde Ocak 2014 Ağustos 2016 tarihleri arasında yapıldı. KMD'yi değerlendirmek için çift enerjili X-1şını absorpsiyometrisi yapılan KOAH'lı 92 hastanın verileri tıbbi kayıtlardan elde edildi. Osteopeni/osteoporoz T ve Z skorları ile değerlendirildi.

Bulgular: Hastaların ortalama yaşı $66.2 \pm 9.2$ idi ve erkekler çalışma grubunun \%89.1'ini oluşturuyordu. KOAH hastalarında osteopeni/osteoporoz sıklı̆̆1 \%63.0 idi. Osteopeni/osteoporoz sıklığı GOLD evre C/D ve GOLD evre A/B hastalarda aynıydı [12/19 (\%63.1) ve 46/73 (\%63.1)]. Osteoporozu olan hastaların bir önceki y1l alevlenme sayıları ve yeniden basvuru oranları daha yüksek; hastanede kalış süreleri daha uzundu $(\mathrm{p}<0.05)$. Vücut kitle indeksi ile KMD $(\mathrm{r}=0.489, \mathrm{p}<0.001), \mathrm{KMD}$ ile FEV1/FVC $(\mathrm{r}=0.226, \mathrm{p}=0.040)$, KMD ile önceki y1l alevlenme sayıs1 $(\mathrm{r}=-0.429, \mathrm{p}=0.001)$ ve KMD ile hastanede yatış süresi $(r=-0.228, \mathrm{p}=0.034)$ arasında anlamlı bir korelasyon tespit edildi. GOLD evresinin şiddeti arttıkça, osteopeni prevalansı da artmıştı ( $\mathrm{p}_{\text {trend }}<0.001$ ). GOLD evresinin şiddeti arttıkça, osteopeni prevalansı da artmıştır (Ptrend $<0.001$ ).

Sonuç: Verilerimiz KOAH hastalarında evreden bağımsız olarak osteopeni ve osteoporoz sıklığının yüksek olduğunu ortaya koymaktadır. Anormal KMD sonuçları sık alevlenme, hastanede kalış süresinde uzama gibi hastalığın kötü seyri ile ilişkilidir.

Anahtar sözcükler: Kronik obstrüktif akciğer hastalığı; osteopeni; kemik mineral dansitesi, osteoporoz; 1 saniyede zorunlu ekspirasyon hacmi (FEV1) / zorunlu vital kapasite (FVC)

\section{INTRODUCTION}

Chronic Obstructive Pulmonary Disease (COPD) is a major cause of morbidity and mortality in adults and it is the fourth leading cause of death in the world ${ }^{1}$. COPD is now considered as a multicomponent disorder associated with systemic inflammation and extra pulmonary manifestations ${ }^{2}$. Osteoporosis is characterized by low bone mineral density (BMD) and alterations in microarchitecture, increasing the risk of fractures, imposing lower mobility and leading to changes in postural balance. The World Health Organization defines osteoporosis as a bone density $\geq 2.5$ standard deviations below the bone density of a normal young adult ${ }^{3}$.

Osteoporosis prevalance is estimated to be 2 to 5 times higher in COPD patients as compared to healthy subjects ${ }^{4,5}$. Currently the overall prevalence of osteoporosis in COPD is reported as $35.1 \%$, ranging from $8.7 \%$ to $69 \%$ and proposed that it was more commonly seen in ill patients and patients with frequent exacerbation ${ }^{6}$. Osteoporosis in COPD may result from several conditions that eventually ended up with vitamin D deficiency and bone resorption. However, there is a limited Turkish data about the association between COPD and BMD. The aim of this cohort study was to estimate the prevalance of osteopenia and osteoporosis in patients with COPD. The secondary objective was to determine the correlation between BMD and the clinical characteristics of COPD patients.

\section{MATERIAL AND METHODS}

\section{Study Design}

This retrospective cohort study of 92 patients was conducted in the Department of Pulmonary
Medicine at a University Hospital in Turkey from January 2014 to August 2016. Spirometrically proven COPD patients who were hospitalized for COPD exacerbation and underwent BMD measurement were included in the study. 1) Patients with bronchial asthma; 2) Patients on long term oral steroids; 3) Patients with coexisting lung diseases such as pulmonary tuberculosis and bronchiectasis; 4) Patients with chronic comorbidities including congestive heart failure, chronic liver disease and 5) Patients with recent acute coronary syndrome were excluded.

Demographic data of the index admission, prebronchodilator pulmonary function tests (PFTs); comorbidities, the exacerbation history of previous year, the usage of long-term oxygen treatment (LTOT) or noninvasive mechanical ventilation (NIMV), C-reactive protein (CRP), erythrocyte sedimentation rate (ESR), arterial blood gases, intensive care unit (ICU) admissions, the results of BMD and the readmission rate within 30 days after discharge had been recorded.

\section{Diagnosis of COPD}

The diagnosis of COPD was established according to the Global Initiative for Obstructive Lung Disease (GOLD) Guideline in a stable condition. Accordingly, a forced expiratory volume in one second/forced vital capacity (FEV1/FVC) $<0,7$ and a compatible medical history were required for the diagnosis ${ }^{1}$.

\section{Measurement of Pulmonary Functions}

Pulmonary function tests were performed with Sensor Medics Vmax20 Spirometer in sitting position while wearing a noseclip. Three full inspiration and forced expiration maneuvers were performed according to the European Respiratory 
Society (ERS) Criteria. The recorded values were taken from the best of three forced expiratory measurements ${ }^{7}$.

\section{Evaluation of COPD Severity}

Patients with COPD were classified according to the degree of airflow obstruction (FEV1) into moderate obstruction (50-79\%), severe obstruction (30-49\%), and very severe obstruction $(<30 \%)^{1}$. The COPD severity was determined according to the GOLD index, which is based on the postbronchodilator FEV1, history of exacerbations in the previous year, and symptoms such as dyspnea (measured with the mMRC or CAT), and classified the study groups A, B, C, and $\mathrm{D}^{1}$.

\section{Measurement of Bone Mineral Density}

Bone mineral density (BMD); was measured with dual-energy x-ray absorptiometry (DEXA), which is used to define osteoporosis and provides a useful estimate of fracture risk [8]. According to the World Health Organization (WHO), a T score greater than -1 is accepted as normal, $\mathrm{T}$ scores between -1 and -2.5 are classified as osteopenia, and $\mathrm{T}$ scores of less than -2.5 are defined as osteoporosis. A Z-score of -2.0 or lower is accepted as "below the expected range for age", and a Z-score above -2.0 is "within the expected range for age" $"$.

\section{Evaluation of comorbidities}

Comorbidities were recorded if it was proven by patient's self-declaration or by medical records. Additional lung conditions, such as pneumonia, pulmonary embolism, bronchiectasis and lung carcinoma, were defined by radiological findings and an appropriate clinical picture on the decision of attending doctors.
Statistical Analysis

Parametric data are presented as means \pm SDs, and categorical data are presented as either percentages of the total or numbers as appropriate. Numerical data were compared using the Student's t-test, one-way ANOVA, or MannWhitney $U$ test. Categorical variables were compared using the chi-square test or Fisher's exact test. A test for trend was performed using the linear-by-linear association method. The Pearson's correlation analysis was performed to assess the association between BMD and COPD characteristics. Significance was determined at $5 \%$ level.

\section{RESULTS}

Ninety-two patients hospitalized for worsening of COPD has been included in the study. The majority of the patients were men (M/F: 82/10). The mean age was $66.2 \pm 9.2$ years. Half of the patients were between 60 and 74 years old. A large number of patients 87 (94.6\%) were smokers (40 were current smokers, 47 were ex-smokers). Based on FEV1, 66 (72\%) patients had moderate obstruction, $16(26.7 \%)$ had severe obstruction while only $1(1.7 \%)$ had very severe obstruction. There were no patients with mild obstruction. Overall, 58 (63.1\%) patients had an abnormal BMD of which 34 (37.0\%) had osteopenia and 24 (26.1) patients had osteoporosis. Among the osteoporotic patients, $20(83.4 \%)$ patients had GOLD stage C-D, while 4 (16.6\%) had GOLD B. Out of the 34 patients with normal BMD scores, 7 (20.5\%) GOLD A-B had while 27 (79.4\%) GOLD stage C-D. Out of 37 patients with GOLD stage D 25 (79.4\%) had osteoporosis. Baseline characteristics are shown in (Table 1). 
Table 1: Main characteristics of study group according to Bone Mineral Density

\begin{tabular}{|c|c|c|c|}
\hline Characteristics & $\begin{array}{c}\text { Normal BMD } \\
(\mathrm{n}=34, \%)\end{array}$ & $\begin{array}{c}\text { Osteopenia } \\
(\mathrm{n}=34, \%)\end{array}$ & $\begin{array}{c}\text { Osteoporosis } \\
(n=24, \%)\end{array}$ \\
\hline \multicolumn{4}{|l|}{ Gender } \\
\hline Male & $29(85)$ & $31(91)$ & $22(92)$ \\
\hline Female & $5(15)$ & $3(9)$ & $2(8)$ \\
\hline \multicolumn{4}{|l|}{ Age groups (years) } \\
\hline $40-59$ & $9(28.5)$ & $8(23.5)$ & $1(4.2)$ \\
\hline $60-74$ & $14(41.2)$ & $17(50.0)$ & $15(62.5)$ \\
\hline$\geq 75$ & $11(32.4)$ & $9(28.5)$ & $8(33.3)$ \\
\hline \multicolumn{4}{|l|}{ Smoking Habit } \\
\hline Current smoker & $11(32.4)$ & $12(35.3)$ & $10(41.7)$ \\
\hline Never smoked & $1(2.9)$ & $2(5.9)$ & $2(8.3)$ \\
\hline Ex-smoker & $19(55.9)$ & $18(52.9)$ & $10(41.7)$ \\
\hline Passive smoker & $3(8.8)$ & $2(5.9)$ & $2(8.3)$ \\
\hline \multicolumn{4}{|l|}{ GOLD Stage } \\
\hline Stage A & $1(2.9)$ & $1(2.9)$ & - \\
\hline Stage B & $6(17.6)$ & $7(20.6)$ & $4(16.6)$ \\
\hline Stage C & $15(44.1)$ & $11(32.4)$ & $10(41.7)$ \\
\hline Stage D & $12(35.3)$ & $15(44.1)$ & $10(41.7)$ \\
\hline Mean $\mathrm{FEV}_{1}(\%)( \pm \mathrm{SD})$ & $40.6 \pm 16.05$ & $40.8 \pm 19$ & $36.2 \pm 14.9$ \\
\hline Mean $\mathrm{FEV}_{1} / \mathrm{FVC}(\%)( \pm \mathrm{SD})$ & $55.4 \pm 10.3$ & $53.5 \pm 14.7$ & $49.8 \pm 9.5$ \\
\hline Mean T/Z Score ( $( \pm S D)$ & $0.45 \pm 0.94$ & $-1.72 \pm 0.4$ & $-3.51 \pm 0.78$ \\
\hline Mean Femur T score $( \pm \mathrm{SD})$ & $-0.75 \pm 0.89$ & $-1.37 \pm 0.98$ & $-1.95 \pm 1$ \\
\hline Mean Lumbal T score $( \pm \mathrm{SD})$ & $0.04 \pm 0.94$ & $-1.71 \pm 0.39$ & $-3.51 \pm 0.77$ \\
\hline Mean Femur Z score $( \pm \mathrm{SD})$ & $0.42 \pm 0.82$ & $-0.39 \pm 0.85$ & $-0.85 \pm 0.65$ \\
\hline Mean Lumbal Z score \pm SD) & $0.74 \pm 1.15$ & $-0.8 \pm 0.64$ & $-2.1 \pm 1.16$ \\
\hline
\end{tabular}

BMD:Bone mineral density, SD:Standard deviation, GOLD: Global Initiative for Obstructive Lung Disease,

$F E V_{1}$ :Forced expiratory volume in 1 second, FVC:forced vital capacity

Body mass index (BMI) of patients with normal BMD was higher than patients with osteopenia/osteoporosis $(\mathrm{p}=0.005)$. Exacerbation number of patients with osteoporosis in previous year was higher than patients with osteopenia (2 vs $1, \mathrm{p}=0.002$ ). Median duration of hospital stay of patients with osteoporosis was longer than patients with normal BMD (14 vs 12 days, $\mathrm{p}=0.044$ ). Also readmission rate of patients with osteoporosis was higher than both patients with osteopenia $(70.8 \%$ vs $26.5 \%, \mathrm{p}=0.001)$ and patients with normal BMD (70.8\% vs $32.3 \%$, $\mathrm{p}=0.001$ ).

There was no difference regarding demographic characteristics, smoking habit, pulmonary functional parameters, comorbidity number, ICU admission number, LTOT and NIMV usages, arterial $\mathrm{PaO} 2$ and $\mathrm{PaCO} 2$, laboratory parameters including hemogram, hematocrit, CRP and ESR 
between normal BMD, osteopenia and osteoporosis patient groups $(\mathrm{p}>0.05)($ Table 2$)$.

Table 2: Comparison of demographic and clinical charateristics of patients with normal and abnormal bone mineral density

\begin{tabular}{|c|c|c|c|c|}
\hline Variables & $\begin{array}{c}\text { Normal } \\
\operatorname{BMD}(\mathbf{n}, \%)\end{array}$ & $\begin{array}{l}\text { Osteopenia } \\
(\mathbf{n}, \%)\end{array}$ & $\begin{array}{l}\text { Osteoporosis } \\
(\mathbf{n}, \%)\end{array}$ & \\
\hline & Mean \pm SD & Mean \pm SD & Mean \pm SD & \\
\hline Age & $68.6 \pm 9.8$ & $66.1 \pm 10.8$ & $71.3 \pm 7.9$ & 0.276 \\
\hline BMI (m2/kg) & $30.8 \pm 7.7$ & $26.3 \pm 3.8$ & $23.7 \pm 5.1$ & 0.005 \\
\hline $\begin{array}{l}\text { Number of cigarette } \\
\text { (pack/year) (median) [25- } \\
\text { 75] }\end{array}$ & $68.9 \pm 49.1$ & $57.1 \pm 29.6$ & $67.7 \pm 32.9$ & 0.559 \\
\hline $\begin{array}{l}\text { Median number of } \\
\text { comorbidity [25-75] }\end{array}$ & $2.2 \pm 1.9$ & $1.8 \pm 1.5$ & $2.2 \pm 1.6$ & 0.596 \\
\hline $\begin{array}{l}\text { Number of having more } \\
\text { than } 3 \text { comorbidities }\end{array}$ & $5(14.7)$ & $4(11.7)$ & $4(16.7)$ & 0.72 \\
\hline $\begin{array}{l}\text { Exacerbation number in } \\
\text { the previous year } \\
\text { (median) [25-75] }\end{array}$ & $1(1-2)$ & $1(1-2)$ & $2(2-4)$ & 0.002 \\
\hline $\begin{array}{l}\text { Duration of hospital stay } \\
\text { in admission } \\
(\text { day)(median)[25-75] }\end{array}$ & $12(7-15)$ & $10(8-14)$ & $14(10-22.5)$ & 0.044 \\
\hline $\begin{array}{l}\text { Number of patients who } \\
\text { had readmission }\end{array}$ & $11(32.3)$ & $9(26.5)$ & $17(70.8)$ & 0.001 \\
\hline $\begin{array}{l}\text { Number of patients } \\
\text { admitted ICU in the } \\
\text { previous year }\end{array}$ & $3(9)$ & $5(15)$ & $7(29)$ & 0.124 \\
\hline $\begin{array}{l}\text { Number of patients on } \\
\text { LTOT }\end{array}$ & $14(41)$ & $11(32.4)$ & $11(45.8)$ & 0.714 \\
\hline $\begin{array}{l}\text { Number of patients on } \\
\text { NIMV }\end{array}$ & $3(9)$ & $2(6)$ & $4(17)$ & 0.382 \\
\hline FEV1/FVC & $55.4 \pm 10.3$ & $53.5 \pm 14.7$ & $49.8 \pm 9.5$ & 0.021 \\
\hline FEV1 (\%) & $40.6 \pm 16$ & $40.8 \pm 18.9$ & $36.2 \pm 14.9$ & 0.291 \\
\hline $\operatorname{FVC}(\%)$ & $56.1 \pm 16.6$ & $57.2 \pm 16.3$ & $55.8 \pm 16.9$ & 0.918 \\
\hline $\mathrm{PaO2}$ (mmHg) & $56.8 \pm 10.9$ & $56.3 \pm 10.2$ & $57.3 \pm 11.8$ & 0.957 \\
\hline PaCO2 (mmHg) & $42.5 \pm 8.5$ & $43.8 \pm 13.3$ & $42 \pm 10.6$ & 0.776 \\
\hline Hemoglobin (gr/dL) & $14.2 \pm 1.9$ & $14.4 \pm 1.9$ & $13.8 \pm 1.9$ & 0.629 \\
\hline Hematocrit (\%) & $42.9 \pm 6.1$ & $43.8 \pm 6.9$ & $39.8 \pm 7.8$ & 0.325 \\
\hline CRP (mg/dl) & $33.6 \pm 90.4$ & $39.7 \pm 64.2$ & $50.4 \pm 57.3$ & 0.056 \\
\hline ESR (mm/saat) & $28.4 \pm 22.8$ & $34.5 \pm 25.8$ & $37.9 \pm 30$ & 0.29 \\
\hline
\end{tabular}

BMD:Bone Mineral Density,ICU:Intensive care unit, LTOT: Long-term oxygen therapy, NIMV:Noninvasive mechanical ventilation, $F E V_{1}$ :Forced expiratory volume in 1 second, FVC:forced vital capacity, CRP: C-Reactive Protein, ESR: Erythrocyte Sedimentation Rate 
Correlation analysis revealed that there are correlations between BMD and BMI, FEV1/FVC and exacerbation numbers in the previous year and the duration of hospital stay in admission (Table 3).

The frequency of osteoporosis/osteopenia according to GOLD stages in patients with COPD as follow: GOLD A 50\% (1/2), GOLD B $64.7 \%$ (11/17), GOLD C 58.3\% (21/36), GOLD D 67.6\% (25/37). As the severity of the disease increased, osteoporosis prevalence was significantly higher in patients with GOLD stage $\mathrm{C}$ or D than in those with GOLD stage A or B (ptrend=0.03).

Table 3: Correlation coefficeints (r) of body mineral density with biochemical parametres and pulmonary functions and clinical parameters

\begin{tabular}{|c|c|c|}
\hline Characteristics & r coefficient & p value \\
\hline Gender (male) & 0.078 & 0.459 \\
\hline Age (years) & -0.094 & 0.374 \\
\hline BMI (m2/kg) & 0.489 & $<0.001$ \\
\hline Smoking habit (package/year) & -0.040 & 0.719 \\
\hline Comorbidity number & -0.050 & 0.646 \\
\hline $\begin{array}{l}\text { Exacerbation number in the } \\
\text { previous year }\end{array}$ & -0.429 & 0.001 \\
\hline $\begin{array}{l}\text { Duration of hospital stay in } \\
\text { admission (day) }\end{array}$ & -0.228 & 0.034 \\
\hline LTOT use & -0.096 & 0.378 \\
\hline NIMV use & -0.152 & 0.175 \\
\hline ICU admission & -0.228 & 0.034 \\
\hline $\mathrm{FEV}_{1}(\%)$ & 0.139 & 0.217 \\
\hline $\mathrm{FVC}(\%)$ & 0.035 & 0.757 \\
\hline $\mathrm{FEV}_{1} / \mathrm{FVC}(\%)$ & 0.229 & 0.040 \\
\hline $\mathrm{PaO} 2(\mathrm{mmHg})$ & -0.088 & 0.495 \\
\hline $\mathrm{PaCO} 2$ (mmHg) & -0.043 & 0.740 \\
\hline $\mathrm{Hg}(\mathrm{gr} / \mathrm{dL})$ & 0.132 & 0.230 \\
\hline Hct $(\%)$ & 0.166 & 0.140 \\
\hline CRP (mg/ dL) & -1.666 & 0.161 \\
\hline ESR (mm/saat) & -0.126 & 0.264 \\
\hline
\end{tabular}

ICU:Intensive care unit, LTOT: Long-term oxygen therapy, NIMV:Noninvasive mechanical ventilation, FEV $V_{1}$ :Forced expiratory volume in 1 second, FVC:forced vital capacity, CRP: C-Reactive Protein, ESR: Erythrocyte Sedimentation Rate 


\section{DISCUSSION}

This study evaluated the prevalance of osteoporosis/osteopenia and the relationship between BMD results and COPD severity and prognosis in patients with COPD. The prevalance of osteopenia and osteoporosis were high in COPD patients. Osteoporosis in COPD was more frequent in GOLD C-D patients with higher exacerbation and readmission rates, with longer hospital stay and with lower BMI. As the severity of the disease increased, osteoporosis prevalence was increased in our cohort.

Osteoporosis is a disease with features of microarchitectural destruction of bone tissue leading to a low bone density, increased bone fragility and thus increased fracture risk $^{4}$. Osteopenia is the preclinical stage of osteoporosis. Multiple mechanisms have been postulated to explain the high prevalence such as smoking, inflammatory cytokine production, vitamin D deficiency, physical inactivity and use of steroids ${ }^{10}$.

The prevalance of osteoporosis in COPD patients was $26.1 \%$ in our study, it was lower than the $35 \%$ found in a systematic review ${ }^{6}$ and lower than that found $42 \%$ recently in a study carried out by Silva et $\mathrm{al}^{11}$. Soriano et $\mathrm{al}^{12}$ found a bone mass loss of $75 \%$ in their patients with COPD. Although our patients were more severe $\left(\mathrm{FEV}_{1}\right.$ $36.2 \%$ ), when we considered osteopenia and osteoporosis together, the frequency of anormal BMD was $63.0 \%$.

The prevalence of osteoporosis was also higher in a major TORCH (TOwards a Revolution in COPD Health) trial which was conducted in an 88 US centers involving 658 patients (a subset of 6,184 international patients in TORCH trial). Baseline and yearly BMD measurements at the hip and spine were performed in their study. At baseline, the overall prevalence of both osteoporosis and osteopenia was found high at $65 \% 13$. Our result $63.0 \%$ was consisitent with this huge study.

Consistent with our findings Graat-Verboom et $\mathrm{al}^{4}$ observed that as severity of COPD increased the prevalence of osteoporosis also increased. The prevalence of osteoporosis was 6\%, 19\%, and $16 \%$ in Stage I, Stage II, and Stage III, respectively, while it increased to $59 \%$ in Stage IV COPD patients ${ }^{4}$. In another study by Vrieze et a ${ }^{15}$ similar findings were found as higher prevalence of osteoporosis in Stage III and Stage IV COPD disease as compared to Stage I and Stage II COPD ${ }^{15}$.

There are very few studies examining the relationship between COPD and osteopenia /osteoporosis in Turkey. In the study of İntepe et $\mathrm{al}^{16}$ the incidence of osteoporosis in COPD patients was compared with the control group. Among 68 COPD patients $52.9 \%$ had mild and $47.1 \%$ had moderate COPD as they made spirometric evaulation. Osteopenia was found as $70.6 \%$ and osteoporosis was found as $29.2 \%$ in COPD patients ${ }^{16}$. In our study, the majority of our patients were in advanced GOLD stages $(39.1 \%$ stage C, $40.2 \%$ stage 4 ) with very few of them in the mild-moderate stage (Stage A-B 20.7\%). In our study, the frequency of osteoporosis according to GOLD stages as follow; GOLD A 0, GOLD B $23.5 \%$, GOLD C $27.7 \%$, GOLD D $27.1 \%$. Although in the study of Intepe et $\mathrm{al}^{16}$ all the COPD patients had mild to moderate COPD, their osteoporosis finding $29.2 \%$ was similar to our finding $27.0 \%$.

Karapolat et a ${ }^{17}$ have investigated the prevalence of osteoporosis in male COPD patients in our country. Interestingly in their study no significant difference was found in BMD and T scores of hip and lumbar areas between COPD and control groups ( $p>0.05)$. They attributed this result to the fact that all patients included in their study had mild to moderate COPD, all patients were physically active, and all had good nutrition status ${ }^{17}$. In our study we had very few patients in GOLD stage A (\%2.2) and stage B (18.5\%), majority of our patients had advanced stage COPD (Stage C and D).

Different from the results of these studies from our country, our study presents data related to the disease course of COPD patients with osteopenia and osteoporosis. We found that patients with osteoporosis had longer readmission rates and longer hospitalizations in accordance with the literature ${ }^{18,19}$.

\section{CONCLUSION}

COPD patients have a higher prevalence of low BMD (osteopenis/osteoporosis) and the latter was associated with the disease severity and poor 
prognosis of the disease including higher readmission rate and frequent exacerbation.

\section{REFERENCES}

1. Global Strategy for the Diagnosis, Management and Prevention of COPD, Global Initiative for Chronic Obstructive Lung Disease (GOLD) 2014. Available from: http://goldcopd.org.

2. Dursunoğlu N, Köktürk N, Baha A, Bilge AK, Börekçi Ş, Çiftçi $F$ et al. Turkish Thoracic Society COPD Comorbidity Group. Comorbities and their impact on chronic obstructive pulmonary disease. Tuberk Toraks 2016;64:292-301.

3. Bolton CE, Ionescu AA, Shiels KM, Pettit RJ, Edwards PH, Stone MD et al. Associated loss of fat-free mass and bone mineral density in chronic obstructive pulmonary disease. Am J Respir Crit Care Med 2004;170:1286-93.

4. Bhattacharyya P, Paul R, Ghosh M, Dey R, Dey $\mathrm{R}$, Barooah $\mathrm{N}$ et al. Prevalence of osteoporosis and osteopenia in advanced chronic obstructive pulmonary disease patients. Lung India 2011;28:184-86.

5. Watanabe R, Inoue D. Secondary osteoporosis. Chronic obstructive pulmonary disease:COPD. Clin Calcium 2018;28(12):1647-1652.

6. Graat-Verboom L, Wouters EF, Smeenk FW, van den Borne BE, Lunde R, Spruit MA. Current status of research on osteoporosis in COPD: a systematic review. Eur Respir J 2009;34:209-18.

7. Miller MR, Crapo R, Hankinson J, Brusasco V, Burgos F, Casaburi R, et al. General considerations for lung function. In: Series "ATS/ERS Task Force: Standardisation of lung function testing”. Eur Respir J 2005;26:153-61.

8. Kanis JA. WHO Study Group Assessment of fracture risk and its application to screening for postmenopausal osteoporosis: synopsis of a WHO report. Osteoporos Int 1994;4(6):368-81.

9. International Society for Clinical Densitometry (ISCD) Official Positions- Adult. Available from: http://www.iscd.org/official-positions/2013-iscdofficial-positions-adult; 2013.

10. Jorgensen NR, Schwarz P, Holme I, Henriksen BM, Petersen LJ, Backer V. The prevalence of osteoporosis in patients with chronic obstructive pulmonary disease: a cross sectional study. Respir Med 2007;101:177-85.

11. Silva DR, Coelho AC, Dumke A, Valentini JD, de Nunes JN, Stefani CL et al. Osteoporosis prevalence and associated factors in patients with
COPD: a cross-sectional study. Respir Care2011;56:961-8.

12. Soriano JB, Visick GT, Muellerova H, Payvandi N, Hansell AL. Patterns of comorbidities in newly diagnosed COPD and asthma in primary care. Chest 2005;128:2099107.

13. Ferguson GT, Calverley PMA, Anderson JA, Jenkins CR, Jones PW, Willits LR et al. Prevalence and progression of osteoporosis in patients with COPD: results from the TOwards a Revolution in COPD Health study. Chest 2009;136(6):1456-1465.

14. Graat-Verboom L, van den Borne BE, Smeenk FW, Spruit MA, Wouters EF. Osteoporosis in COPD outpatients based on bone mineral density and vertebral fractures. $\mathbf{J}$ Bone Miner Res 2011;26(3):561-8.

15. Vrieze A, de Greef MH, Wijkstra PJ, Wempe JB. Low bone mineral density in COPD patients related to worse lung function, low weight and decreased fat-free mass. Osteoporos Int 2007;18(9):1197-202.

16.İntepe YS, Yıldırım E, Metin B, Karaçavuş S, Balbaloğlu Ö, Korkmaz M. The Evaluation of Bone Mineral Density in Patients With Chronic Obstructive Pulmonary Disease. Bozok Tip Derg 2016;1(1):20-6.

17. Karapolat H, Eyigör S, Gürgün A, Kirazlı Y, Başoğlu KÖ, Durmaz B. The Evaluation of Osteoporosis in Male Patients with COPD. Osteoporoz DünyasIndan 2007;13:70-4.

18. Graumam RQ, Pinheiro MM, Nery LE, Castro CHM. Increased rate of osteoporosis, low lean mass, and fragility fractures in COPD patients: association with disease severity. Osteoporos Int 2018;29(6):1457-1468.

19. Lee SH, Kwon HY. Prevalence of Osteoporosis in Korean Patients with Chronic Obstructive Pulmonary Diseaseand Their Healthrelated Quality of Life According to the Korea National Health and Nutrition Examination Survey 2008-2011. J Bone Metab 2017;24(4):241248. 